\title{
THE PALEOECOLOGICAL SIGNIFICANCE OF NERINEOID MASS ACCUMULATIONS FROM THE KIMMERIDGIAN OF THE SWISS JURA MOUNTAINS
}

\author{
RICHARD WAITE $1 *$ ANDREAS WETZEL,${ }^{2}$ CHRISTIAN A. MEYER,${ }^{3}$ and ANDRÉ STRASSER ${ }^{1}$ \\ ${ }^{1}$ University of Fribourg, Department of Geosciences, Pérolles, Chemin du Musée 6, CH-1700 Fribourg, Switzerland; '2University of Basel, Institute of Geology and \\ Paleontology, Bernoullistrasse 32, CH-4056 Basel, Switzerland; ${ }^{3}$ Natural History Museum Basel, Augustinergasse 2, CH-4001 Basel, Switzerland \\ e-mail: richard.waite@unifr.ch
}

\begin{abstract}
The Kimmeridgian shallow-water carbonates of the Swiss Jura Mountains display stratigraphic levels containing mass accumulations of nerineoidean gastropods. The macro- and microfacies of the rocks with these nerineoidean assemblages suggest that their occurrence was related to water depth, physical energy within the habitat, sedimentation rate, substrate stability, and food supply. Typical nerineoidean shells are high spired and exhibit unique spiral laminae (folds) on the internal walls. Mass accumulations consisting of large, heavy individuals are believed to represent a semisessile, suspensionfeeding community that utilized an external food source. During times of enhanced precipitation and run-off from the hinterland, terrestrial organic matter may have been supplied into the shallow sea, thus forming a source of food for the nerineoids. Alternatively, relative sea-level change during transgression may have led to largescale coastal erosion and flooding of the platform, also potentially leading to a mobilization of organic matter. Size and morphology of the high-spired shells seem to indicate a trend toward maximal external volume. Development of folds within the shell is interpreted as a modification to maintain a small internal volume. The faunal and floral composition of the strata indicates a suspension-rich, highenergy environment with a low-sedimentation rate and a stable substrate. This allowed mass colonization by epifaunal nerineoids, which, in turn, formed a frameworklike structure. The heavy shells acted as a grid, trapping the sediment in between. In this way, a reinforced carbonate accumulation formed.
\end{abstract}

\section{INTRODUCTION}

The Nerineoidea was one of the most diverse gastropod superfamilies in the Tethyan realm (Sohl, 1987), and the Late Jurassic represents the phase of maximum radiation (Korotkov, 1997). Nerineoid occurrences have been reported from Mesozoic deposits around the world, including Asia, Europe, Africa, and North and South America (e.g., Wieczorek, 1992). They are also known locally from Pacific seamounts and the $\mathrm{Ca}$ ribbean (e.g., Woodring, 1952). They had both wide longitudinal and latitudinal representation, although they are less common at higher paleolatitudes (Ziegler, 1964; Sohl, 1987; Saul and Squires, 2002). The superfamily Nerineoidea ranges from the Hettangian to the Maastrichtian (Pchelintsev, 1965; Barker, 1990, 1994).

In the Jurassic platform carbonates of Switzerland, nerineoids are common constituents, and nerineoid mass accumulations have been reported from the Bajocian (Strübin, 1914, 1916; Gonzalez, 1993) and the Kimmeridgian (Häfeli, 1966; Dauwalder and Remane, 1979) of northwestern Switzerland. These beds extend laterally for kilometers and vary in thickness from a few centimeters to $4 \mathrm{~m}$. In the Kimmeridgian, nerineoideandominated deposits of the Reuchenette Formation have been used as marker beds (Thalmann, 1966). In certain intervals, estimated population

* Corresponding author. densities exceed 27,000 specimens $\cdot \mathrm{m}^{-3}$ (Dauwalder and Remane, 1979). The Late Jurassic-Early Cretaceous was a period of radiation of the nerineoids (Korotkov, 1997), and during this time interval new environments on the extensive carbonate platforms of Europe were colonized.

Nerineoids are known for their distinctive internal spiral lamellae-or simply, folds-which developed inside the whorls of the shells. These are present in many, though not all, genera. This paper provides a new approach to the interpretation of the unique shape of the nerineoids and to its relevance in the formation of the nerineoid mass accumulations.

\section{GEOLOGICAL SETTING}

During Kimmeridgian times, the region of the Swiss Jura Mountains formed part of a carbonate platform that extended from the Paris Basin in the northwest to the Tethys Ocean in the southeast (Fig. 1A). The marine fauna and flora indicate tropical-to-subtropical temperatures (Frakes et al., 1992). The area was located at a paleolatitude of $\sim 30^{\circ} \mathrm{N}$ (Thierry et al., 2000). It was connected to the London-Brabant Massif in the north, and during times of emergence of the platform, it may have formed a land bridge to the Central Massif in the southwest. Recurrent dinosaur track levels document large populations of herbivorous and carnivorous dinosaurs and evidence the periodic emergences (e.g., Marty et al., 2003). From the shallow-water limestones that formed on the platform, several occurrences of nerineoid accumulations have been reported, especially from northwestern Switzerland. Among them are occurrences from the region of Porrentruy and one famous occurrence, the so-called Solothurn Turtle Limestone (e.g., Meyer, 1994), at Lommiswil near the city of Solothurn on the south foot of the Jura Mountains.

One section near Porrentruy was examined in detail for this studySur Combe Ronde near the village of Courtedoux (Swiss Coordinates: 568.869 / 250.082; World Geodetic System $847.026246^{\circ} \mathrm{E}$; $47.400821^{\circ} \mathrm{N}$; see Fig. 1B). It forms part of an active paleontological excavation site where the Section de Paléontologie de la République et Canton du Jura has been excavating several layers of interest for some years. The studied section has recently been dated as being in the Boreal Aulacostephanoides mutabilis or the Tethyan Aspidoceras acanticum ammonite zones, respectively (Fig. 2A; see Jank et al., 2006). The bedding planes are subhorizontal and have not experienced substantial tectonic deformation. The section consists of shallow-water carbonate sediments interlayered with occasional marls. It has received much attention because several levels with well-preserved dinosaur tracks and trackways have been found (Marty et al., 2003). The Sur Combe Ronde section extends from the main dinosaur levels at the base to the Virgula Marls at the top (Hug et al., 2003), and facies analysis shows a general deepening-upward trend. Sequence-stratigraphic and cyclostratigraphic analysis show 2.5 small-scale sequences between these units, which have been hypothesized to correspond to $100 \mathrm{kyr}$ each (Fig. 2B; see Rameil, 2005).

\section{METHODS}

The exposure of the section at Sur Combe Ronde permits the study and documentation of both the vertical development of the strata and the 


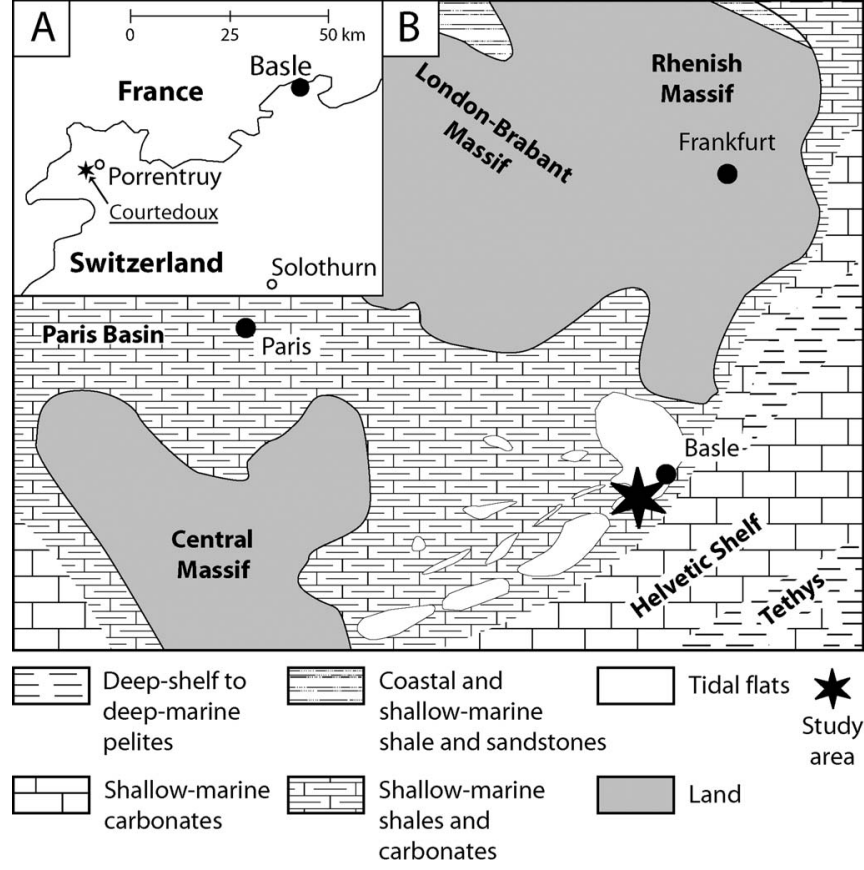

FIGURE 1-Maps of the study area. A) Location of the detailed section. B) Paleogeographical reconstruction in the vicinity of the study area during the Kimmeridgian (redrawn from Jank et al., 2006).

surfaces of the individual layers. A total of 56 samples was collected from this section with an average sample spacing of $15 \mathrm{~cm}$. Thin sections and polished sections were prepared from each sample. Thin sections were stained for dolomite with a mixture of Alizarin Red-S and potassium ferricyanide (Dickson, 1966).
Additional samples were gathered from four sections in northwestern Switzerland, especially from Lommiswil, which were used for comparison. The nerineoid-bearing limestones of Switzerland are frequently used as building stone; therefore, photographs of large polished slabs were taken to demonstrate anatomical features in exceptionally well-preserved specimens or interesting features of population distribution.

\section{SUR COMBE RONDE SECTION}

\section{Description of the Nerineoids}

A distinctive feature of most nerineoid shells is the development of internal spiral folds, which are, by convention, denoted as columellar (C), parietal (P), labial or labral (L), and basal (B) folds. If, for example, C $=1, \mathrm{P}=1, \mathrm{~L}=1$, and $\mathrm{B}=0$, the fold formula can be given as 1.1.1.0. (Wieczorek, 1979; Barker, 1990; Fig. 3). Classification of nerineoid genera with no folds is extremely difficult when no external sculptures can be examined.

Six genera were found in the studied section. Three of these, namely Ptygmatis Sharpe, 1850, Cryptoplocus Pictet and Campiche, 1896, and Eunerinea Cox, 1949, can easily be classified because they exhibit a characteristic fold pattern. In addition, Ptygmatis and Cryptoplocus both have an umbilicus (Fig. 4). Itieria Matheron, 1842, is relatively easy to identify owing to its egglike shape (Fig. 5A), but the remaining two genera are not well preserved. Furthermore, they are fold free and do not exhibit any clear features that would allow unequivocal identification in polished section. Based on the rounded base of the shell, one of these genera (Fig. 5B) may be assigned to Pseudonerinea, Ceritella, or Fibula (M.J. Barker, personal communication, 2002). To simplify matters, we refer to these specimens as the Pseudonerinea type. Finally, the last genus is of extremely delicate shape and may represent a very acicular, foldless Contortella Pchelintsev, 1965 (Fig. 5C; M.J. Barker, personal communication, 2002). It is therefore referred to as the Contortella type.

\section{A Studied section}
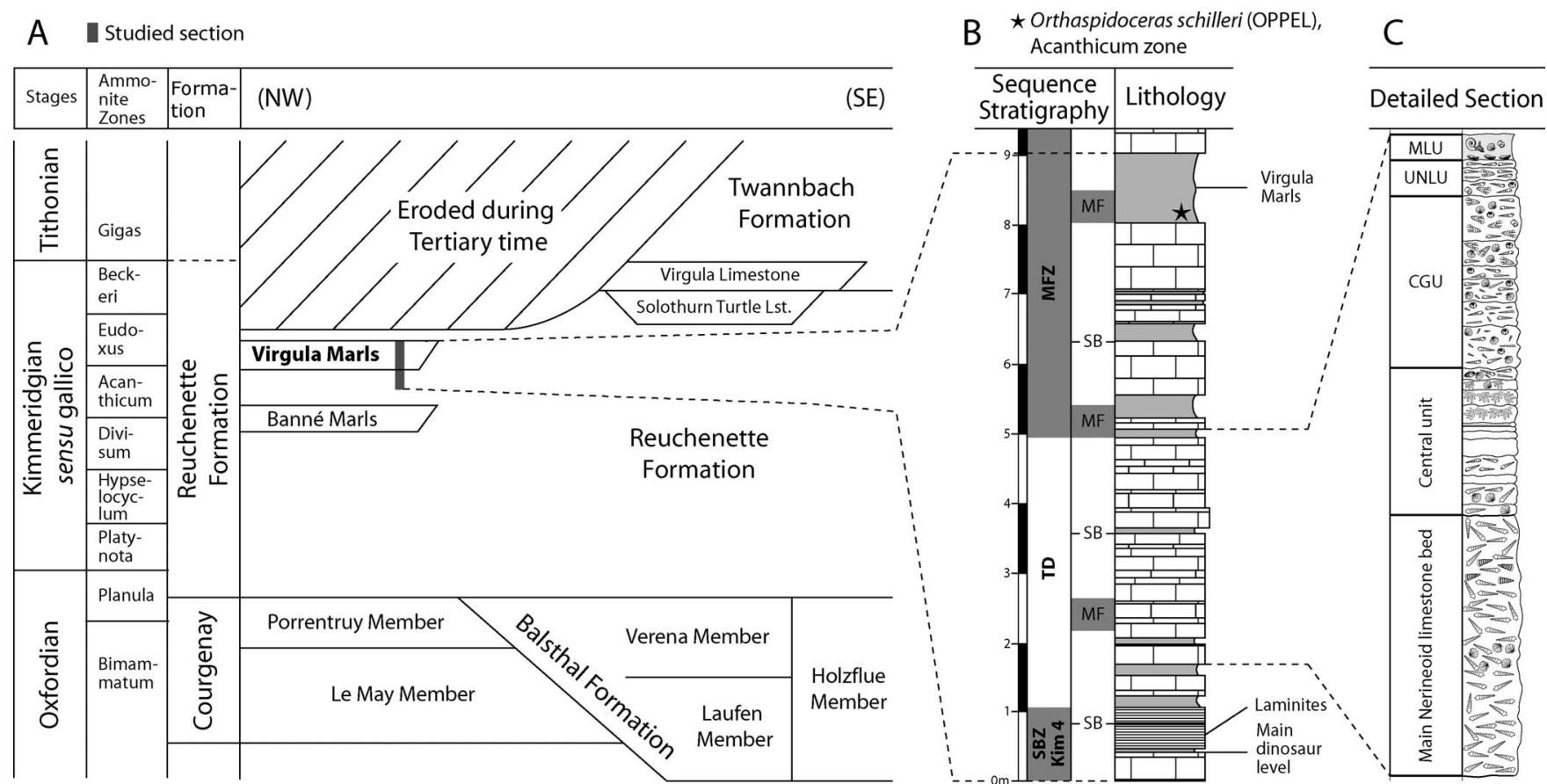

FIGURE 2-Stratigraphy of Reuchenette Formation at Sur Combe Ronde. A) Litho-, bio-, and chronostratigraphy (based on Jank et al., 2006); associated thickness relations are not to scale. B) Schematic profile of the paleontological excavation site at Sur Combe Ronde and the sequence-stratigraphic framework of the section according to Rameil (2005). Columns show large-scale sequences with the boreal sequence boundary zone (SBZ) Kimmeridgian (Kim 4) at the base (left) and superposed small-scale sequences (center). In the lithology column, note the deepening-up trend from the Main Dinosaur Track Level at the base to the Virgula Marls at the top (redrawn from Hug et al., 2003). SB = sequence boundary; TD = transgressive deposit; MF = maximum flooding; MFZ = maximum flooding zone. C) Detailed section at Sur Combe Ronde. $\mathrm{CGU}=$ composite gastropod unit; UNLU = upper nerineoid limestone unit; MLU = marl layer unit. Symbols as in Figs. 6-7. 
A

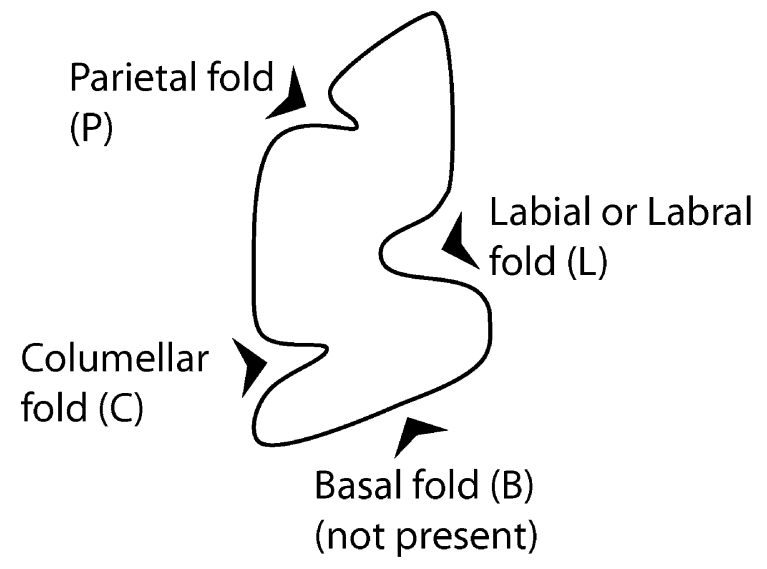

B

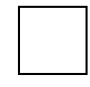

0.0.0.0

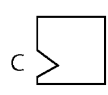

1.0.0.0

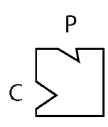

1.1.0.0

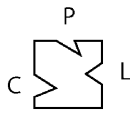

1.1.1.0

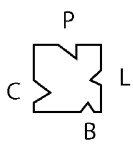

1.1.1.1

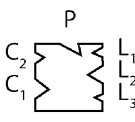

2.1.3.0
FIGURE 3-Nerineoid fold formula and examples. A) Fold nomenclature shown on a whorl cross-section of Eunerinea arduennensis. If $\mathrm{C}=1, \mathrm{P}=1, \mathrm{~L}=1$, and $\mathrm{B}=0$, then the fold formula $=1.1 .1 .0$ (redrawn from Barker, 1990). B) Different schematic examples of fold complexity redrawn from Wieczorek (1979).

\section{Description of the Section}

The studied section forms part of the Reuchenette Formation. It is composed of massive, mainly fossiliferous limestone beds with occasionally intercalated marl layers. It starts about $2 \mathrm{~m}$ above the main dinosaur track level and ends $3 \mathrm{~m}$ below the Virgula Marls (Fig. 2C); therefore, an $~ 3.5$-m-thick interval has been analyzed in detail. The top is formed by a hardground overlain by a 20 -cm-thick marl layer, which preserves a rich fauna with ammonites, nautilids, and many vertebrate fossils. Based on the macro- and microfaunal constituents and the lithology, five units have been distinguished within the section from base to top (Figs. 6 and 7):

Main Nerineoid Limestone Bed.-The Main Nerineoid Limestone Bed (MNLB) is $1.5 \mathrm{~m}$ thick and mainly composed of massive limestone, occasionally interlayered with thin marl deposits (Fig. 6). The interval is easily distinguished by the innumerable shells of the nerineoid genus Eunerinea (estimated at 7,000 specimens $\cdot \mathrm{m}^{-3}$ ). Although the shells are preferentially oriented parallel or slightly oblique to the bedding plane, a preferential orientation within the plane has not been observed (see also Dauwalder and Remane, 1979). Other complete macrofossils are very rare; therefore, the bed represents a monogeneric assemblage. The carbonate is essentially composed of echinoderm and bivalve fragments, calcispheres, calcimicrobes, benthic foraminifera, and red and green calcareous algae. In thin section the texture appears as fossiliferous, dedolomitized mudstone to wackestone, with calcitic microspar and macrospar precipitated in cavities. In pockets, however, the micritized remnants of grains that consisted of peloids and intraclasts can be seen. There are two pronounced changes of lithology and macrofaunal composition within this unit.

1. In an $\sim 10$-cm-thick layer (layer $22 / \mathrm{e}$ ), bivalves are the dominant macroscopic fossils, although Eunerinea is still present. The bivalve shells are not articulated, occur in a hydrodynamically stable position, and are of approximately the same size. The lithology changes to a marlstone, which is less compact, brittle, and wavy bedded. In thin section, the components appear heavily micritized, and the initial grainstone texture is hard to discern. The diversity and abundance of the microfauna is reduced.
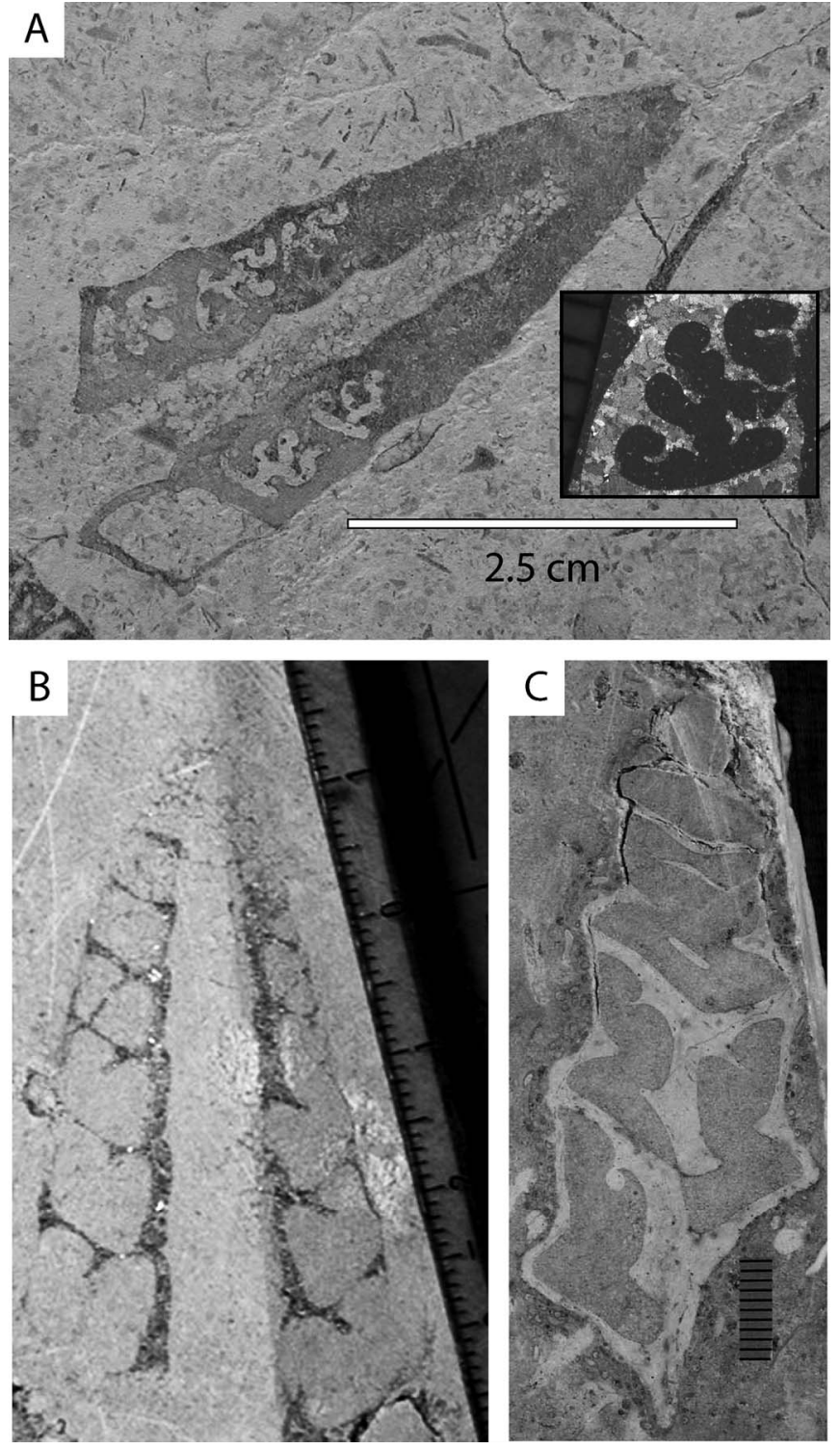

FIGURE 4-Polished sections of A) Ptygmatis (5 folds, 2.1.2.0); inset shows a closeup of the fold pattern. B) Cryptoplocus (1 fold, 0.1.0.0); and C) Eunerinea (3 folds, 1.1.1.0). Scale bars in $B$ and $C$ in $\mathrm{mm}$. See Figure 3 for an explanation of folds.

2. In a 20-cm-thick interval (layer 22/b), the composition of the macrofauna changes notably. Eunerinea is replaced by Ptygmatis as the dominant nerineoid genus, although the macrofauna nonetheless appears monogeneric. The micritization of the components is not pronounced in this interval, and a rich microfauna is present.

Apart from these two intervals, which indicate relatively short term changes, the MNLB represents an environment subject to continuous sedimentation for several tens of thousands of years.

Central Unit.-The Central Unit (CU) separates the relatively uniform MNLB at the base from the composite gastropod unit above. The CU comprises several different intervals (layers 21-10; Figs. 6-7). Layers 21-18 record the gradual cessation of the nerineoid limestone sedimentation; bivalves appear concomitantly, and bioturbation becomes more pronounced. Nerineoids are first reduced in abundance, then the composition changes, and in layer 18 the Pseudonerinea type is dominant.

Layers 17-13 of the CU evidence a regression and subsequent emergence (corresponding to a small-scale sequence boundary; see Fig. 2). 

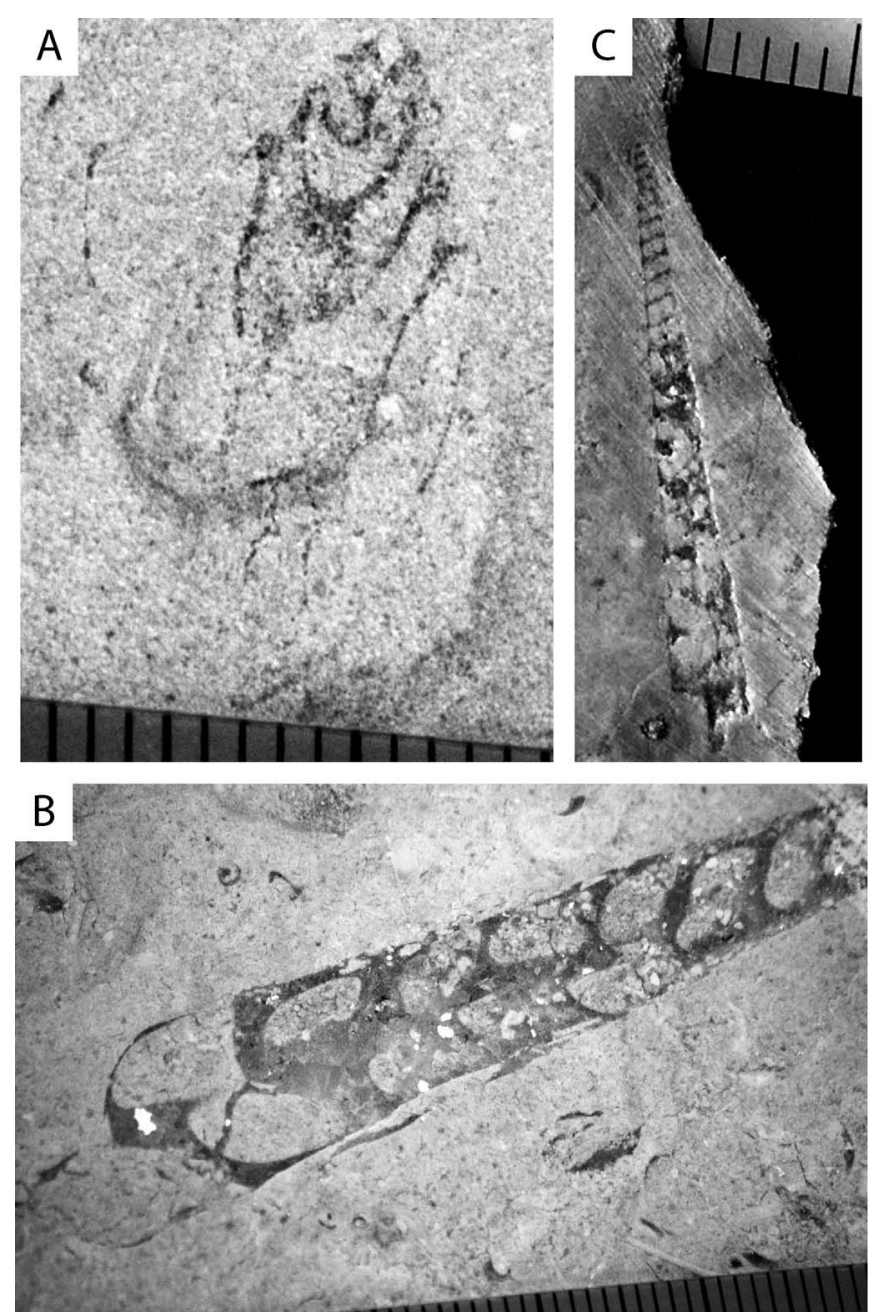

FIGURE 5-Polished sections of A) Itieria (2 folds, 1.0.1.0); B) Pseudonerinea type (0 folds, 0.0.0.0); and C) Contortella type (0 folds, 0.0.0.0). Scale bars in mm. See Figure 3 for an explanation of folds.

Three levels of laminites, one of them showing ripple marks at the base of layer 14, are overlain by a horizon of dinosaur trampling (layer 13).

Layers 12-10 record a flooding and the onset of the deposition of the Pseudonerinea-type and Contortella-type nerineoid assemblage. In layers 12 and 11 microfossils are very rare, but in layer 11 large bivalves occur. Layer 10 is distinctive; although only about $6 \mathrm{~cm}$ thick, it is internally layered. The base is characterized by densely packed bivalve shells, and the upper part is dominated by nerineoids of the Pseudonerinea type. Frequent occurrences of Itieria, a few Eunerinea, and occasional specimens of the Contortella type have been recorded, however, as well as bivalve shells. This layer shows the most diverse population of nerineoids throughout the studied section. Excavation work in layers 10 and 9 also revealed a rich fauna containing vertebrate remains, oysters, and black pebbles (Hug et al., 2003). The sediment is an unmicritized grainstone. It can be interpreted as a high-energy deposit where important reworking and winnowing occurred.

The Composite Gastropod Unit.-The Composite Gastropod Unit (CGU) is composed of a relatively uniform, only slightly micritized, dedolomitized grainstone (Fig. 7). The macrofauna is dominated by nerineoids of the Pseudonerinea type, occurring together with subordinate specimens of the Contortella type and Eunerinea (layers 9-6). In layers 5-4, dominant Cryptoplocus occurs with frequent Pseudonerinea-type specimens (Fig. 7). Further constituents throughout the unit are abundant echinoids (mainly Pygurus), bivalves, and other gastropods. Although the nerineoids are present throughout this unit, they do not reach the abundance seen in the MNLB. There are always at least two genera of nerineoids and other macrofaunal constituents present; therefore, although the CGU contains nerineoids, it does not represent a mass accumulation. The numerous echinoids point to stenohaline, full-marine conditions.

The Upper Nerineoid Limestone Unit (UNLU).-The UNLU is characterized by nerineoid shells as abundant as in the MNLB (Fig. 7). The top of layer 1 is capped by a hardground, which records maximum flooding of the small-scale sequence (Fig. 2). It is overlain by a 20 -cm-thick marl layer (MLU, layer 0), which contains glauconite (Jank et al., 2006). The UNLU contains skeletal remains of vertebrates, brachiopods, bivalves, and echinoids (Hug et al., 2003). Nerineoids of the Pseudonerinea and Contortella types as well as Cryptoplocus and Eunerinea occur. The Pseudonerinea type is the dominant form and very abundant; Cryptoplocus and Eunerinea are about equally frequent, but the Contortella type is rare. Layers 3-1 show a gradual change of color toward the hardground, becoming increasingly reddish brown. The hardground itself is bored and has been encrusted with serpulids and oysters. The gastropod shells within the hardground were completely dissolved; in some cases the voids of the shells were subsequently filled with micrite containing echinoderm fragments and other biogenic remains. In other cases the remaining steinkern was eroded, and nerineoid-shaped molds are a regular feature of the hardground. This unit has experienced substantial reworking of faunal elements and condensation at the hardground. It has therefore been excluded from the subsequent discussion, as any paleoecological interpretations concerning the nerineoids would be biased.

The Marl Layer Unit (MLU).--The MLU marks an abrupt change in lithology (Fig. 7). This layer contains numerous remains of a rich vertebrate fauna, including crocodile teeth, fish, sharks, turtle shells, and other bones. In addition, both nautilids and ammonites have been recovered. The benthic invertebrate fauna is composed of brachiopods, oysters, echinoids, bivalves, and gastropods. Remains of crustaceans and trace fossils (mainly Thalassinoides) have also been found (Hug et al., 2003). As in the lithologically similar Virgula Marls (Deecke, 1916), however, no nerineoids occur in this layer.

\section{MORPHOLOGY OF THE NERINEOIDS}

\section{Shell Structure}

Fossil shells of the superfamily Nerineoidea are usually slender, tower shaped, cylindrical to conical, or egg shaped (Wenz, 1939; Pchelintsev, 1965 ) and vary in size from a few millimeters (Pan, 1990) to $>60 \mathrm{~cm}$ (M.J. Barker, personal communication, 2005). The majority of nerineoids are high spired. The thread is either massive or hollow (umbilicate). The nerineoids can be foldless or develop a simple or complex pattern of internal folds on the columella and the outer lip. The folds can reduce the internal shell space by $>50 \%$ (Wenz, 1939; Barker, 1990, 1994). Because the nerineoids continuously grew during their life, they lack a clear terminal growth feature defining adulthood (Deecke, 1916; Barker, 1994; but see also Wieczorek, 1979). The diagnostic taxonomic characters of the superfamily are the presence of a juxtasutural selenizone (slitband), a rudimentary siphonal canal, and a heterostrophic protoconch (Barker, 1990, 1994; see Fig. 8).

The original shell structure does not normally survive diagenesis, and, hence, there is no information on the preservation of the operculum, periostracum, or original color of the nerineoids. Only in very rare cases have the original aragonitic, crossed-lamellar shell microstructure, and the early-lithified remnants of a duct system in the digestive gland-gonad complex been described (Barker, 1990).

In many nerineoid genera, a secondary thickening of the shell has been observed. The thinnest parts of the adult shell are the lips of the aperture (Wieczorek, 1979). There the shell grows by secretion of new carbonate from the mantle epithelium. Secondary internal layers are progressively secreted over the previous lips or external layers (Wieczorek, 1979). In the fold-bearing genera, the folds are incrementally emplaced over the 


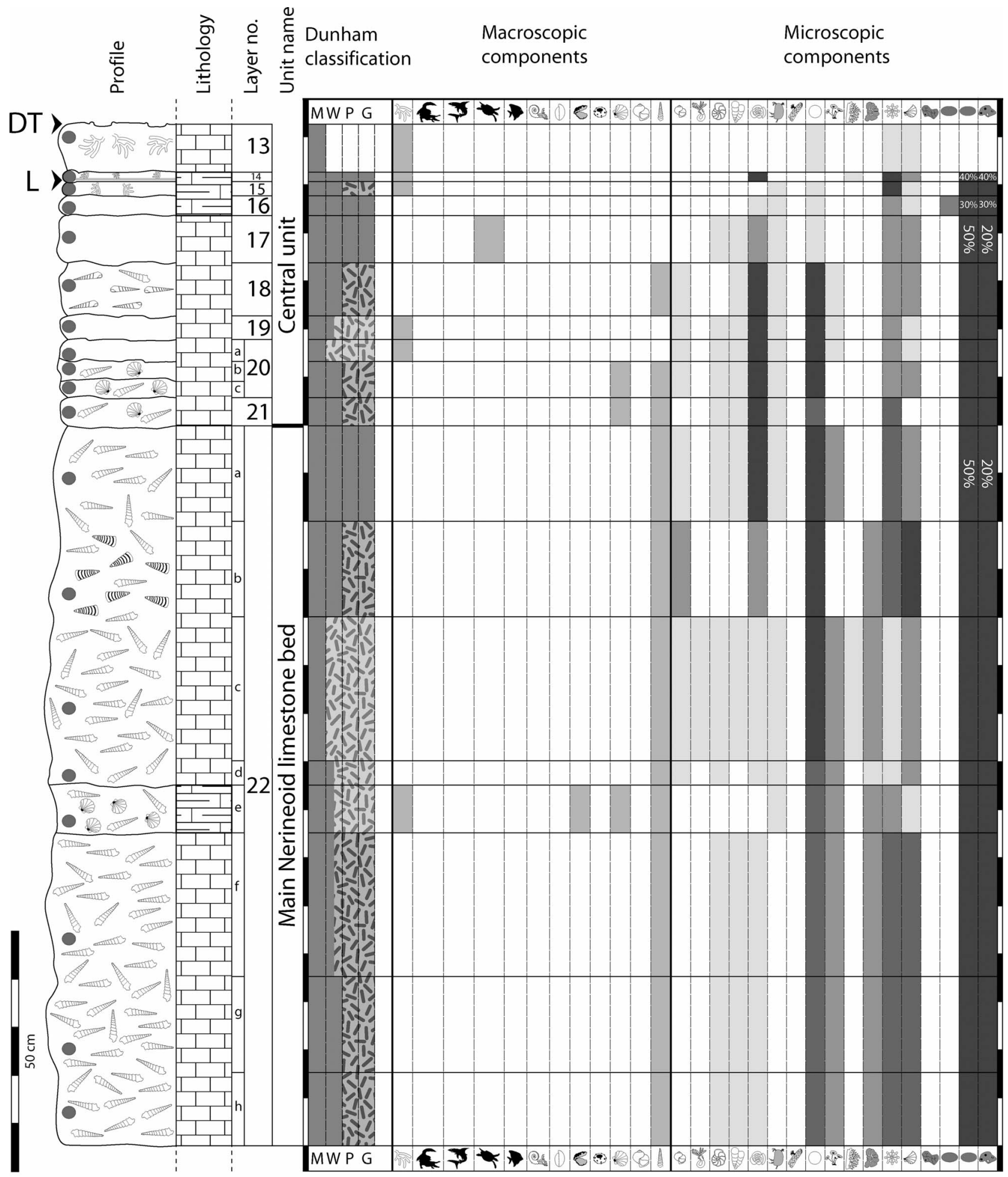

Relative frequencies (total thin section area):

\section{$50 \%$ Very abundant with relative percentage}

Abundant

Frequent
Rare

Present (macroscopic assemblage)
Sediment structures and lithology:

Sil Strongly micritized peloids

Micritized peloids

Laminites
Marly Limestone

Marl
Burrows 
internal layers, as the soft parts of the animal that occupy the terminal whorls successively move downward relative to the apex (Barker, 1990). The internal sculpture of fold-bearing nerineoids is unique. Juvenile whorls are fold free, but folds are incrementally emplaced as the animal grows, and their morphology becomes progressively more complex. The complexity of the folds gradually but rapidly declines in the adapical part of the penultimate whorl, and the final part of the last whorl always remains free of folds (Wieczorek, 1979; Barker, 1990). Finally the tip of the shell may be completely filled with aragonite, especially in large specimens (e.g., Tiedt, 1958; Wieczorek, 1979; Lysenko, 1983; Barker, 1990). In some nerineoids buttressing of the whorls along the spire is incomplete, and an umbilicus is formed.

Some features are to a certain extent also common in extant gastropods, including (1) a high-spired shell, (2) thickening of the shell, (3) spiral folds, (4) filling of the apex, and (5) formation of an umbilicus. For these, data are available in the literature that may help resolve the mode of life of the nerineoids.

High-Spired Shell.-Gastropod shells are stated to have two major functions: protection and support of the internal viscera (e.g., Andrews, 1974; Savazzi, 1999). The exchange with the environment happens via the aperture. If the aperture becomes too large, the protective function is limited (Andrews, 1974). A narrow aperture insures protection but reduces the diameter of the mantle cavity and the amount of water passing through it. These competing aspects may be a reason for the development of a high spire. It enables the formation of a long mantle cavity accommodating a long gill while maintaining a small aperture (Andrews, 1974). In forms with a small aperture and a long mantle cavity, the development of a siphonal canal increases the water inflow and supports optimum circulation (Djalilov, 1975).

Various authors have discussed the high-spired shell shape and ascribed its development mainly to a protective function, enabling the gastropod to withdraw deep into the shell when under attack (Signor and Kat 1984; Vermeij, 1989; Aberhan et al., 2006). This appears to be especially important with respect to the attacks of lip-pealing Calappidae (Vermeij et al., 1980; Allmon, 1988). The high spire can also have other advantages, however. For example, it is known to enable terrestrial gastropods to hide in narrow cracks (Savazzi, 1999). Barker (1990) noted that all modern high-spired marine gastropods are at least partially infaunal. This may indicate that the high-spired shell shape is advantageous for a burrowing mode of life. Not all burrowing gastropods are high spired, however, and it has been pointed out that by no means all high-spired forms are infaunal (G.J. Vermeij, personal communication, 2007). Andrews (1974) remarked that many ciliary feeders with an exposed aperture have a many-whorled, turreted shape. He believed that in these cases the high-spired shape is advantageous for housing the complicated feeding apparatus.

Shell Thickening.-Shell thickening can be observed in many extant and fossil forms living in agitated zones influenced by strong water currents (Deecke, 1916). The increase in shell thickness strengthens the shell against damage by water energy and is an effective way to counter predation.

Spiral Folds.-Although there are no comparable morphological equivalents of the nerineoid folds in extant gastropods, shells with internal folds are not unusual, especially in the different families with a highspired morphology (Deecke, 1916). For instance, columellar folds in turritelliform gastropods may represent an adaptation to keep the columellar muscle in place and prevent it from shifting when under tension (Signor, 1982). As the columellar muscle carries the shell, a special modification of the anatomy and strengthening of the muscles is required in highspired gastropods (Deecke, 1916). Price (2003) concluded, however, that columellar folds are unlikely to be related to the guiding of the columellar muscle.

Apex Filling.-Filling of the apex in high-spired gastropods has been described by Andrews (1974). The protoconch and parts of the apical whorl of high-spired gastropods are often broken off during life. The tip of the shell, however, does not remain open because one or several secondary septa are secreted between the tip and the body whorl. In some forms of Turritella, the entire apical end may become filled with calcareous material. Secondarily secreted material strengthens the apex and additionally enables the animal to vacate the upper whorls when encountering surface area versus volume problems - that is, when the soft body parts that occupy the spire are growing more slowly than the shell (Andrews, 1974).

Umbilicus Formation.-An umbilicus is created by the incomplete overlap of adjacent whorls and, according to Vermeij (1993), generally decreases the stability of the shell, especially with respect to crushing. The development of the umbilicus may be related to the way the shell is carried and has been proposed to balance its weight (Deecke, 1916); for example, it can lower the shell's centre of gravity (Vermeij, 1993). Gastropods with umbilicate shells are less common in extant forms than they were during the Mesozoic (Vermeij, 1977, 1993), and, in general, recent high-spired shells lack an umbilicus. Since an umbilicus enlarges the cross section of the shell, umbilicate shells are unusual in infaunal forms, and the presence of an umbilicus suggests a nonburrowing mode of life (Signor, 1982).

\section{Anatomy}

The anatomy and geometry of the internal organs of the nerineoids are interpreted from the morphology of the fossil remains of the hard parts and inferred by analogy to modern gastropods. Apart from the foot and the head when drawn in, the last whorl housed most of the viscera in the visceral sac and the mantle cavity with the gill. The gonads, kidney, and anus all discharged into the mantle cavity. The originally paired organs were likely reduced. This was especially the case for the gill, as only in forms with a single gill could the aperture have become elongated (Linsley, 1977), but it was also true for the osphradium, kidney, and digestive gland (Ziegler, 1983). In all nerineoids, folds were absent in the youngest whorls. The labial fold developed last and, therefore, was farthest away from the aperture, leaving the outer lip of the mantle cavity fold free (Barker, 1990). Most of the spire was occupied by the digestive glandgonad complex, which absorbed nutrients, excreted waste, produced gametes, and stored energy (Fretter and Graham, 1976). In fold-bearing nerineoid shells, therefore, the digestive gland-gonad complex was located between the fully developed folds, as indicated by the remnants of the duct system (Barker, 1990). Since the nerineoids have no obvious living relatives (Wenz, 1939; Barker, 1990), their feeding habits and mode of life can be deduced only from their shell morphology and their host deposits.

\section{DISCUSSION AND INTERPRETATION}

\section{Mass Accumulation}

In the studied section, several layers contain densely packed nerineoids, but intermittently, there are beds with no, few, or frequent nerineoids.

$\leftarrow$

FIGURE 6- Macro- and microfaunal skeletal elements, frequency grayscale code, sedimentary structures, lithologies, and components for lower part of the detailed section at Sur Combe Ronde. The macrofaunal assemblage has no grayscale code and provides information only on the presence of any given skeletal element on the basis of the fossil inventory of the Section de Paléontologie. The microfaunal assemblage provides estimates on relative frequencies of skeletal elements and components. The signatures in the Dunham Classification refer to the state of micritization of the peloids. Percentages at far right indicate relative frequencies of very abundant features. For symbols, see legend in Figure $7 . \mathrm{W}=$ wackestone; $\mathrm{G}=$ grainstone; $\mathrm{M}=$ mudstone; $\mathrm{P}=$ packstone; $\mathrm{DT}=$ dinosaur track level; $\mathrm{L}=$ laminites. 


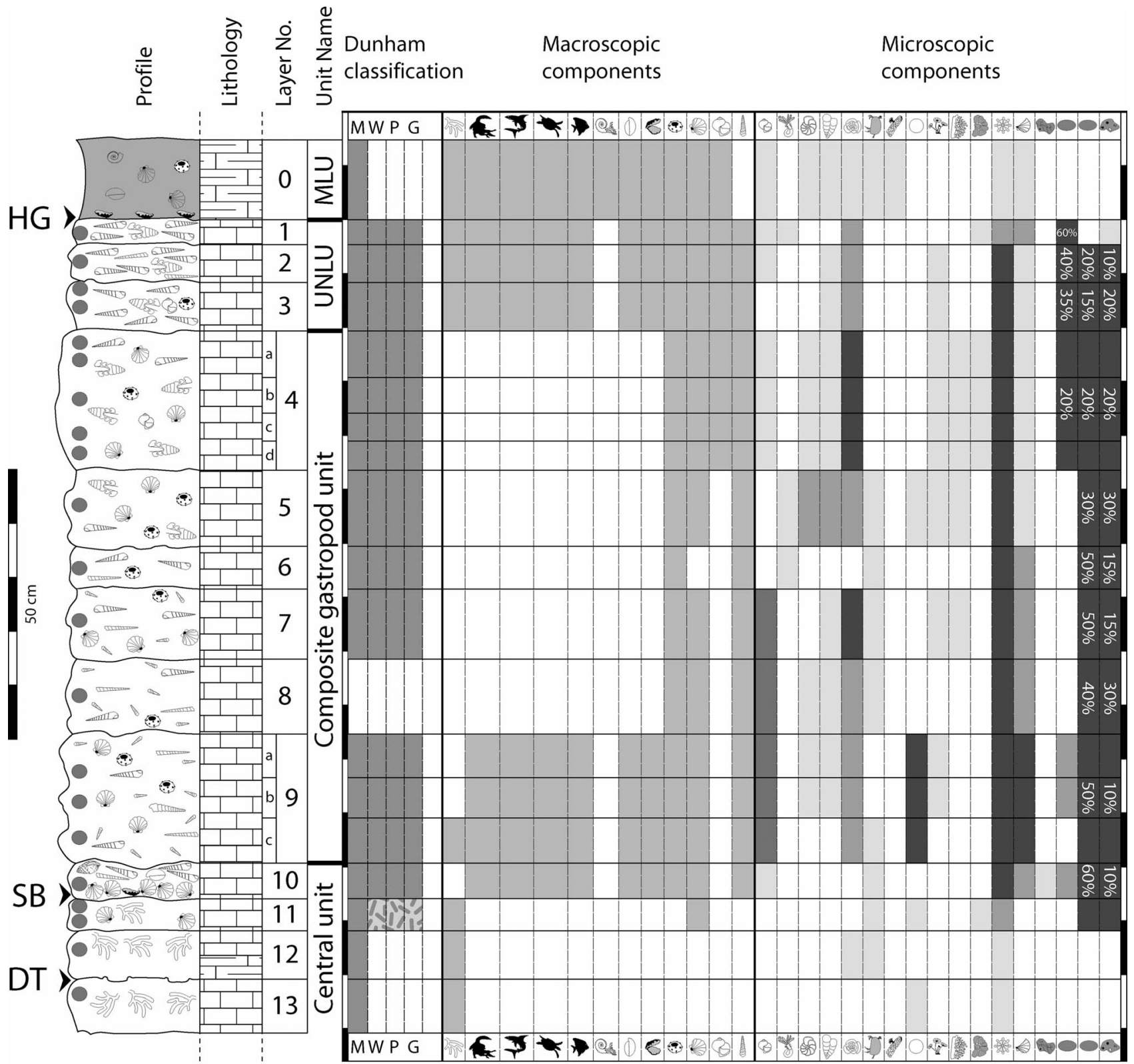

Macrofauna:

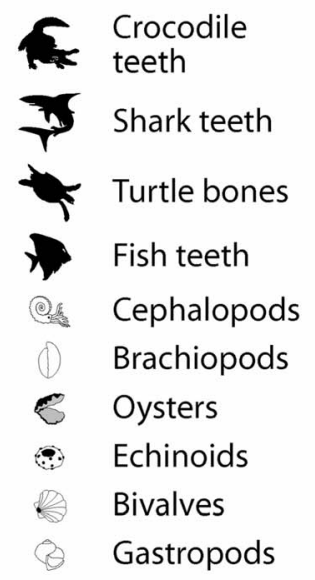

\section{Microfauna:}

Q A Small gastropods

Plane-spiral foraminifers

9 Biserial foraminifers Miliolid foraminifers

3) Ostracodes

- Calcispheres

i Green algae

- Red algae

Calcimicrobes
Nerineoid genera:

Eumbs Eunerinea

- Pseudonerineatype

(4⿴囗十) P) Ptygmatis

Contortella-type

Cryptoplocus

- Itieria

\section{Components:}

A Black pebbles

- Coated grains

- Peloids

a Intraclasts 


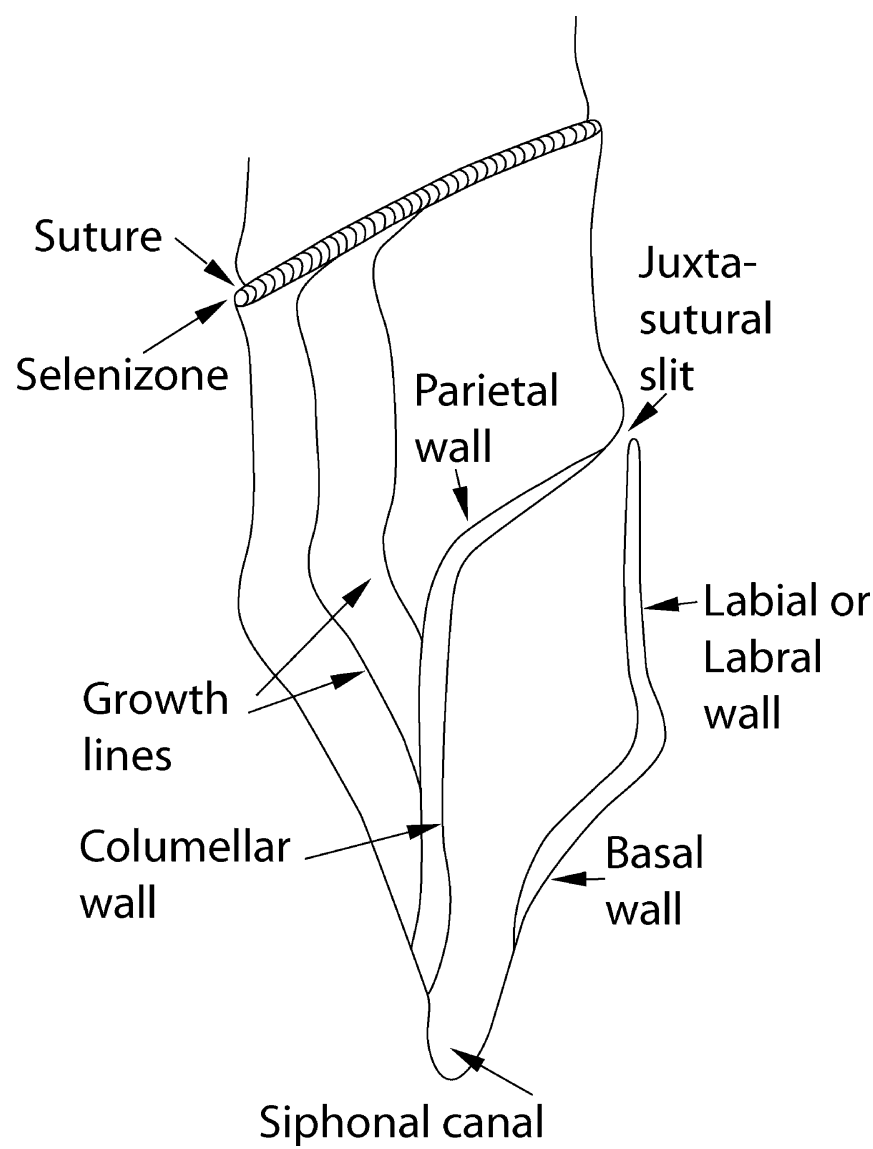

FIGURE 8-Morphological features of nerineoids. For discussion refer to text. Redrawn from Barker (1990).

Environmental factors such as water depth, temperature variation, salinity, food supply, rate of sedimentation, stability of the sediment surface, and water turbulence affect or even control habitat utilization (Fürsich, 1976) and certainly influence the faunal composition in terms of diversity and abundance (Wieczorek, 1979). From the distribution of the nerineoids within the section it becomes apparent that water depth is one limiting factor. The CU shows indication of very shallow water and emersion, while the MLU indicates an open marine environment and relatively deep water. In both, the very shallow water environment nerineoids, as well as the deeper-water environments nerineoids, are absent. Below the CU, the sediment is commonly micritized, and Eunerinea is dominant, while above, micritization is not pronounced, and the Pseudonerinea type becomes dominant. The micritization indicates low-sediment-accumulation rates and thus different habitat utilization possibly related to sediment stability.

Early Liassic nerineoid genera like Pseudonerinea, Nerinella, and Fibula are suggested to resemble infaunal deposit feeders (Barker, 1990; Aberhan et al., 2006). An epifaunal mode of life is ascribed to those genera with strong sculpture and ornamentation that appeared during the Middle Jurassic, such as Eunerinea (Barker, 1990; Sirna, 1995). No shell repair in nerineoids has been reported earlier than the Cretaceous. Shell peeling as a method of predation postdates the radiation of the nerineoids; therefore, the high-spired shell shape may be associated with the originally infaunal mode of life of the nerineoids (Barker, 1990). It less likely reflects deep withdrawal as a defense mechanism for two reasons: (1) deep withdrawal seems difficult, considering that the folds may reduce the internal space by over $50 \%$ and are already present in the last whorl, and (2) during the Early Jurassic, when the nerineoids developed, there were no known predators comparable to the Cenozoic Calappidae that preferentially attack the aperture.

The MNLB is dominated by Eunerinea, which occurs in micritized, dedolomitized grainstones. The Eunerinea shells found in the section are $\leq 20 \mathrm{~cm}$ in length, have three folds, and a relatively thick shell (2.0-2.5 $\mathrm{mm}$ ). The development of a large, thick shell is an efficient method of defense (Vermeij, 1993; Savazzi, 1999), so the most likely reason for the evolution of large, thick-shelled nerineoids is to counter predation. As a secondary advantage, thick shells might also allow colonization of highenergy environments. The early nerineoids are found in low-energy environments and do not colonize reef environments prior to the Late $\mathrm{Ju}$ rassic (Barker, 1990). Potential predators of Eunerinea, which are found in the Sur Combe Ronde section, include starfish, shell-crushing fish, crabs, and possibly benthic cephalopods (Deecke, 1916), as well as marine turtles. The large nerineoid populations in the MNLB (estimated at 7,000 specimens $\cdot \mathrm{m}^{-3}$ ), however, may indicate that the combination of size and thick shells were such an effective means of defense that adult nerineoids became virtually invulnerable. Analysis of size distributions of 114 individuals of Ptygmatis in a monogeneric nerineoid bed has shown that small specimens are rare, with only $\sim 10 \%$ that are $<2 \mathrm{~cm}$ in height. Very small individuals, with less than five whorls, are almost completely absent (Dauwalder and Remane, 1979). Of the five reasons for right-skewed, size-frequency distributions in turritelline populations listed by Allmon (1988), only three appear relevant for the observed population in the studied nerineoid beds. Reason 1, active congregation of adults, and reason 2, adults moving away for egg laying, do not seem likely in the context of the mass accumulations. Allmon's other three reasons, however, all seem possible: reason 3 , predation may preferentially remove juveniles; reason 4 , the species are long-lived and recruitment is infrequent; and reason 5, juveniles may disperse immediately after hatching to areas uninhabited by adults. Gonzalez (1993) proposed that young individuals may have had a different habitat than the adults but did not support this hypothesis with data. Despite detailed analysis of the section at Sur Combe Ronde, no beds have been found that preferentially contain young specimens. Therefore, there is no evidence supporting a different habitat for young nerineoids (reason 5), and a combination of reasons 3 and 4 seem the most likely explanation for the observed population distributions in the MNLB beds.

The MNLB is interpreted to represent an autochthonous-parautochthonous thanatocoenosis in which the shells were transported only over a short distance, if at all, within the original habitat. As the large, heavy shells show no sign of preferential orientation, they are unlikely to be the result of physical enrichment by currents or waves (e.g., Herm, 1977; Dauwalder and Remane, 1979; Wieczorek, 1979; Sirna, 1995). The occasional damage to the fragile apex and the aperture likely represents post-mortem damage resulting from local movement within the original habitat and later compaction.

Red algae, dasycladacean algae, and calcimicrobes are frequent within the massive Eunerinea beds. Fragments of corals, probably originating from patch reefs in close proximity, have also been found. Calcimicrobes, red algae, and serpulids are common encrusters, whereas bryozoans are absent. These observations match those of other authors in nerineoidbearing, Late Jurassic sediments (e.g., Wieczorek, 1975; Geyer and Rosendahl, 1985; Wieczorek, 1992).

FIGURE 7- Macro- and microfaunal skeletal elements, frequency grayscale code, sedimentary structures, lithologies, and components for upper part of the detailed section at Sur Combe Rond. Percentages at far right indicate relative frequencies of very abundant features. $\mathrm{W}=$ wackestone; $\mathrm{G}=$ grainstone; $\mathrm{M}=$ mudstone; $\mathrm{P}=$ packstone; $\mathrm{HG}=$ hardground; $\mathrm{SB}=$ shell bed; DT = dinosaur track level; UNLU = upper nerineoid limestone unit; MLU = marl layer unit. For relative frequencies, sediment structures, and lithology, see legend in Figure 6. 
The initial grainstone composition of the sediment indicates an agitated environment. The strong micritization of the sediment grains implies an environment characterized by low-sedimentation rate and stable substrate. Therefore, the mass accumulations were probably subject to short periods of high water energy, bringing in fresh sediment from adjacent parts of the platform, followed by longer periods of moderate water energy with no substantial sedimentation. The abundant echinoderm fragments and occasional coral fragments point to stenohaline conditions.

The weight, size and shape of the shells are atypical for vagile animals. The very high abundance of Eunerinea in the MNLB, and the long, heavy shell morphology with the concave whorl profile point to a sedentary, suspension-feeding, and epifaunal mode of life. Furthermore, to sustain such a large population, the food must have been supplied from an external source. Possible sources for organic matter are runoff from emerged parts of the platform and reworking of previously emerged and vegetated areas during transgression. The nerineoid mass accumulations are often under- and overlain by dinoturbated layers. These contain imprints and trackways of large herbivorous and carnivorous dinosaurs, showing that land was close to the nerineoid habitat. The presence of recurring dinosaur populations implies vegetation as a food source, and nearby vegetation implies substantial amounts of rain and transport of organic matter and nutrients from the land.

Salinity is an important issue, as nerineoids have sometimes been stated to be indicative of brackish conditions. Many authors have observed that nerineoids may occur together with, or in close proximity to gastropods of the genus Actaeonella (e.g., Woodring, 1952; Tiedt, 1958; Herm, 1977; Pan, 1990). Actaeonellids are reported to have a certain tolerance toward reduced salinity and, therefore, a similar tolerance has been proposed for nerineoids. When they occur together, however, small nerineoids are found together with normal-sized actaeonellids or vice versa, indicating that nerineoids were probably under environmental stress when subjected to abnormal salinity conditions (e.g., Tiedt, 1958). The highest diversities and largest specimens of nerineoids are reported from high-energy environments, where they are found in association with definite indicators of normal marine salinity (Wieczorek, 1979; Barker, 1994).

Independent of the question of salinity, which cannot be unequivocally resolved for the MNLB, the sedimentary facies and faunal and floral composition of this mass accumulation suggest that a special balance between light, water-energy, and food input must have prevailed during its formation. The MNLB formed upon a previously emerged part of the platform in an open-platform environment. Nerineoid shells accumulated together with peloids and intraclasts, as well as bivalve and echinoderm fragments, not far from patch reefs. The occurrence of nerineoids with corals and rudists is not uncommon (e.g., Tiedt, 1958; Vogel, 1968), and thus, the MNLB may be envisaged as a bioconstruction with nerineoids forming a framework similar to rudists. The shells are not attached to each other, but they are heavy and long and may interlock while being oriented in all directions. In this way, they formed a reinforced structure, which acted as a sediment trap and may have been additionally stabilized by microbial and algal growth. Thus, a stabilized, carbonate accumulation developed (Fig. 9), with each successive generation of nerineoids overlying the previous one. Judging from the number of individuals on a bedding surface, food resources did not permit a deposit-feeding mode of life or allow for any substantial mobility; therefore, the population density could only be sustained as long as a constant supply of suspended food was maintained. A change in hydraulic conditions and accumulation rates of organic particles in and around bioconstructions caused by elevated surface roughness are well documented (Yager et al., 1993; Norkko et al., 2001). Therefore, the depressions between the shells may have acted as traps for suspended organic particles providing a constant supply of food. Alternatively, particulate organic matter may have been extracted actively from the water column, for example, by ciliary or mucous-net filter feeding.

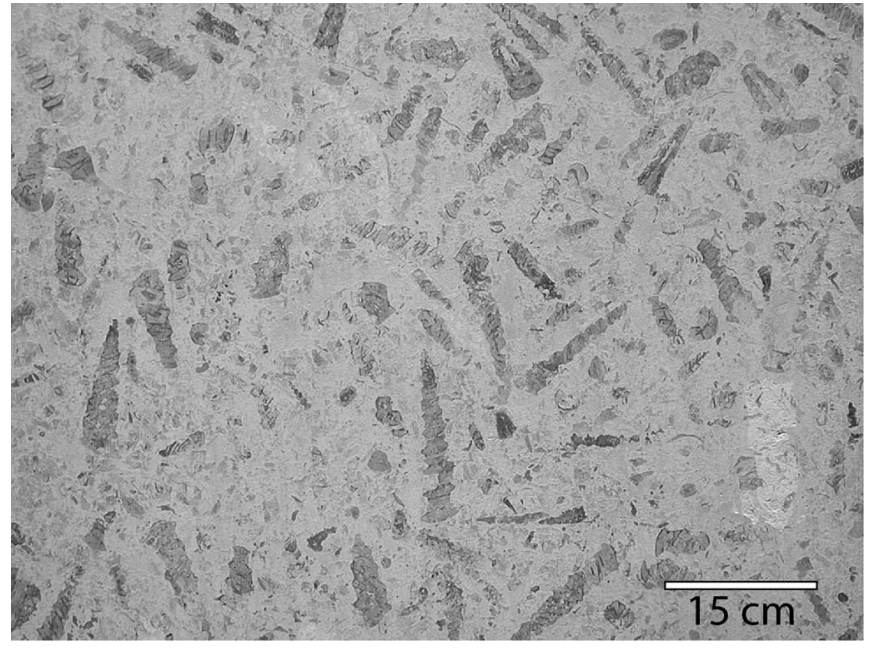

FIGURE 9-Polished slab of the nerineoid mass accumulation from Lommiswil. Plan view.

\section{Fold Development}

Previous authors have assigned the development of the unique internal folds of the nerineoids to (1) strengthening of the shell against damage in high-energy environments (Wenz, 1939), (2) increasing the weight to be less influenced by strong currents (Vogel, 1968), or (3) optimizing the nutrient exploitation when feeding from carbonate-rich deposits (Barker, 1990).

None of these hypotheses, however, is completely satisfactory:

1. Shell thickening and fold development are two separate adaptations, as ontogenetic thickening of the shell occurs prior to the development of the folds (Barker, 1990). The folds are unlikely to represent a primary reinforcement, as the most vulnerable parts of the shell (aperture, apex, and suture) are not strengthened by fold development (Barker, 1990).

2. Heavy shells are advantageous when living in high-energy environments; the increase of weight, however, appears not to be a primary function of the folds. Many nerineoids form an umbilicus that reduces the weight of the shell (Figs. 4A-B). It is doubtful that gastropods increase their weight by fold development as an adaptation to high-energy environments, while at the same time reducing shell weight by forming an umbilicus.

3. If the nerineoids fed on algal coatings of the sediment, they probably also ingested large amounts of carbonate mud. It has been proposed that the folds may have in some way optimized nutrient exploitation. This theory has never been elaborated, however, no comparable extant morphological counterparts exist which would enable testing this proposition. In any case, the high abundance of nerineoids on a bed surface does not support a deposit-feeding habit (e.g., Saul and Squires, 2002).

Based on the studied material, an alternative hypothesis is proposed. As the animal grew, the digestive gland-gonad complex, occupying most of the spire, began to grow at a slower rate than the shell. Similar to turritellines, the infill of the apex in nerineoids was probably a method of vacating the disproportionately small space in the juvenile conch without leaving a cavity, which would generate a surface-area-to-volume problem (Andrews, 1974; Barker, 1990). The infill thus compensated for the excess space in the juvenile spire. The upper whorls were completely filled enabling the animal to vacate the early shell and successively move down the spire. A heavy apex ensured that the shell was drawn down and rested on the sediment surface, so that less surface area was exposed to currents (Vogel, 1968).

A similar function may be attributed to the folds. In the juvenile conch, no folds were formed in order not to impair the function of the vital organs. The gonads were not required to continue growing once sexual maturity had been achieved, however. Also, the digestive gland and the 
volume occupied by the storage cells would have had an optimal size, in terms of energy efficiency, in an animal that is thought to have grown throughout life. Therefore, to maintain a fixed internal volume despite further growth, the formation of simple folds was initiated to compensate for the excess space in the shell. The larger the animal grew, the more space had to be filled. Consequently, the folds became larger and more complex.

This trend to maximum external volume but moderate internal volume was further aided in some forms by the formation of the umbilicus. It enlarged the cross section of the gastropod without forming additional cavity space. A wide, hollow spire maximized the external size and appearance of the gastropod while not changing the internal volume of the whorls. Therefore, some nerineoids appear to have adopted long shells with wide cross sections and thick shells but a small internal volume. The formation of the folds is thought to have been a direct consequence of the elongate shell shape and would primarily have regulated the internal volume of the shell, consequently improving hydraulic stability. This development may have been triggered by the shift from an infaunal to an epifaunal mode of life in the mid-Jurassic. Epifaunal nerineoids would have experienced an increased exposure to predation and currents, which may have favored the adoption of large shells that were additionally thickened by the secretion of internal shell layers.

\section{CONCLUSIONS}

Based on the sedimentological context of the nerineoid mass accumulations in the Kimmeridgian of the Swiss Jura Mountains, the following conclusions can be drawn:

1. The nerineoids observed display large, heavy, sculptured, highspired shells, suggesting an epifaunal mode of life.

2. The increased shell size and thickness are interpreted as a method of counterpredation when living on the sediment surface.

3. As a direct result of the high-spired morphology of the shells, folds were secreted, and the early spire could be completely filled, which would serve to maintain a small internal volume and hydraulic stability.

4. The heavy shells impaired the mobility of the animals, and they adopted a semisessile life, feeding actively or passively off suspended food.

5. As a consequence of this mode of life and the large, invulnerable shells, large numbers of nerineoids colonized stable surfaces in agitated environments where sufficient food was available.

6. The accumulated shells of the nerineoids acted as a sediment trap, thus producing an armored carbonate accumulation.

\section{ACKNOWLEDGMENTS}

Special thanks go to Michael J. Barker (Portsmouth, England) for his help with classification and for the valuable discussions. Thanks also to Daniel Marty and Wolfgang A. Hug, Section de Paléontologie de la République et Canton du Jura, for their excavation data, support, and help and to Klaus Vogel (Frankfurt, Germany) for supplying his famous specimens from Afghanistan and for valuable discussions. Further special thanks go to Markus Jank (Harstad, Norway), Achim Reisdorf, Karl Stransky, and Willy Tschudin (Basel, Switzerland) for invaluable support, discussions, help with fieldwork, and preparation of samples. We would also like to thank the reviewers Geerat J. Vermeij, Warren Allmon, and an anonymous reviewer for their valuable comments, suggestions, and corrections. This research was partially financed by the Swiss National Science Foundation Project 20-109214.05

\section{REFERENCES}

Aberhan, M., Kiessling, W., and Fürsich, FT., 2006, Testing the role of biological interactions in the evolution of mid-Mesozoic marine benthic ecosystems: Paleobiology, v. 32, p. 259-277.
Allmon, W.D., 1988, Ecology of recent turritelline gastropods (Prosobranchia, Turritellidae): Current knowledge and paleontological implications: PALAIOS, v. 3, p. 259-284.

ANDREws, H.E., 1974, Morphometrics and functional morphology of Turritella mortoni: Journal of Paleontology, v. 48, p. 1126-1140.

BARKer, M.J., 1990, The palaeobiology of Nerineacean gastropods: Historical Biology, v. 3, p. 249-264.

BARKER, M.J., 1994, The biostratigraphic potential of nerineacean gastropods-Case studies from the Middle Jurassic of England and the Upper Jurassic of France: Géobios, v. 17, p. 93-101.

Dauwalder, P., and Remane, J., 1979, Untersuchung der Grenznerineenbank zwischen "Kimmeridgien" und "Portlandien" im südlichen Neuenburger Jura: Paläontologische Zeitschrift, v. 53, p. 163-181.

DeEcKe, W., 1916, Paläontologische Betrachtungen: Pt. 9, Über Gastropoden: Neues Jahrbuch für Mineralogie, Geologie und Paläontologie, v. 60, p. 759-788.

Dickson, J.A.D., 1966, Carbonate identification and genesis as revealed by staining: Journal of Sedimentary Petrology, v. 36, p. 491-505.

Dualilov, M.R., 1975, On the systematics of nerineids (Gastropoda): Paleontological Journal, v. 9, p. 2-30.

Frakes, L.A., Francis, J.E., and Syktus, J.I., eds., 1992, Climate modes of the Phanerozoic: The History of the Earth's Climate over the Past 600 Million Years: Cambridge University Press, Cambridge, UK, 274 p.

Fretter, V., and Graham, A., eds., 1976, A Functional Anatomy of Invertebrates: Academic Press, London, 575 p.

FÜrsICH, F.T., 1976, Fauna-substrate relationships in the Corallian of England and Normandy: Lethaia, v. 9, p. 343-356.

Geyer, O.F., and Rosendahl, S., 1985, Stromatoporen, Korallen und Nerineen aus oberjurassischen und unterkretazischen Schichten des Präbetikums von Cazorla (Provinz Jaén, Spanien): Arbeiten aus dem Institut für Geologie und Paläontologie an der Universität Stuttgart, Neue Folge, v. 82, p. 161-180.

Gonzalez, R., 1993, Die Hauptrogenstein Formaton der Nordwestschweiz: Dissertationen aus dem Geologisch-Paläontologischen Institut der Universität Basel: Ph.D. diss., University of Basel, v. 2, 188 p.

HÄFELI, C., 1966, Jura/Kreide-Grenzschichten im Bielerseegebiet: Eclogae Geologicae Helvetiae, v. 59, p. 565-696.

Herm, D., 1977, Zyklische Regressions-Sedimentation und Fossil-Vergesellschaftungen in der Gosau von Brandenberg (Tirol): Mitteilungen der Bayerischen Staatssammlung für Paläontologie und Historische Geologie, v. 17, p. 257-277.

Hug, W.A., Marty, D., Lapaire, F., and Oriet, A., 2003, Raport d'Activités 2002. Paléontologie et Transjurane no. 3: Section de Paléontologie, Canton du Jura, Delémont, Switzerland, $110 \mathrm{p}$.

Jank, M., MeYer, C.A., and Wetzel, A., 2006, Late Oxfordian to late Kimmeridgian carbonate deposits of NW Switzerland (Swiss Jura): Stratigraphical and palaeogeographical implications in the transition area between the Paris Basin and the Tethys: Sedimentary Geology, v. 186, p. 237-263.

Korotкov, V.A., 1997, The Jurassic-Cretaceous phase in the evolution of Nerineids (Gastropoda): Paleontological Journal, v. 31, p. 595-599.

Linsley, R.M., 1977, Some "laws" of gastropod shell form: Paleobiology, v. 3, p. 196-206.

LYSENKO, N.I., 1983, The morphogenesis of the inner spiral folding in shells of nerineids (Gastropoda): Paleontological Journal, v. 17, p. 125-129.

Marty, D., Hug, W.A., and Iberg, A., 2003, Preliminary report on the Courtedoux Dinosaur Tracksite from the Kimmeridgian of northern Switzerland: Ichnos, v. 10, p. 209-219.

Meyer, C.A., 1994, Depositional environment and paleoecology of the Solothurn Turtle Limestone (Kimmeridgian, northern Switzerland): Géobios, v. 16, p. 227 236.

Norkкo, A., Hewitt, J.E., Thrush, S.F., and Funnel, G.A., 2001, Benthic-pelagic coupling and suspension-feeding bivalves: Linking site-specific sediment flux and biodeposition to benthic community structure: Limnology and Oceanography, v. 46, p. 2067-2072.

Pan, H.-Z., 1990, Late Cretaceous gastropod dominated communities of the western Tarim Basin, southern Xinjang, China: Lethaia, v. 23, p. 273-289.

Pchelintsev, V. F., ed., 1965, Mesozoic Murchisoniata from the strata of the Crimean mountains: Science Publishing House Moscow, Moscow, 215 p.

Price, R.M., 2003, Columellar muscle of Neogastropods: Muscle attachment and the function of columellar folds: Biological Bulletin, v. 205, p. 351-366.

RameIL, N., 2005, Carbonate sedimentology, sequence stratigraphy and cyclostratigraphy of the Tithonian in the Swiss and French Jura Mountains: Geofocus, v. 13: Département de Géosciences, Université de Fribourg, Fribourg, Switzerland, $264 \mathrm{p}$.

SAUL, L.R., and SQuires, R.L., 2002, Added nerineoid gastropod evidence for a warm Turonian sea in southern California: Journal of Paleontology, v. 76, p. 386-390.

SAvAzzi, E., ed., 1999, Functional Morphology of the Invertebrate Skeleton: John Wiley \& Sons, Chichester, UK, 718 p.

SignoR, P.W., 1982, Resolution of life habits using multiple morphologic criteria: 
Shell form and life mode in turritelliform gastropods: Paleobiology, v. 8, p. 378388.

SignoR, P.W., and Kat, P.W., 1984, Functional significance of columellar folds in turritelliform gastropods: Journal of Paleontology, v. 58, p. 210-216.

SIRNA, G., 1995, The nerineoids: taxonomy, stratigraphy and paleoecology with particular references to Italian examples: Geologica Romana, v. 31, p. 285-306.

SoHL, N.F., 1987, Cretaceous gastropods: Contrasts between Tethys and temperate provinces: Journal of Paleontology, v. 61, p. 1085-1111.

StrüBin, K., 1914, Die stratigraphische Stellung der Schichten mit Nerinea baseliensis am Wartenberg und in anderen Gebieten des Basler Jura: Verhandlungen der Naturforschenden Gesellschaft Basel, v. 25, p. 203-211.

StrüBin, K., 1916, Nerinea baseliensis, THURM., aus der unteren Hauptrogenstein Formation der Umgebung von Basel: Verhandlungen der Naturforschenden $\mathrm{Ge}-$ sellschaft Basel, v. 27, p. 5-10.

ThaLmann, H.K., 1966, Zur Stratigraphie des oberen Malm im Solothurner Jura: Mitteilungen der Naturforschenden Gesellschaft des Kantons Solothurn, v. 22, p. $6-126$.

Thierry, J., Abbate, E., Alekseev, A.S., Ait, O.R., Ait, S.H., Bouaziz, S., Canerot, J., Georgiev, G., Guiraud, R., Hirsch, F., Ivanik, M., Le, M.J., Le, N.Y.M., Medina, F., Mouty, M., Nazarevich, B., Nikishin, A.M., Page, K., Panov, D.L., Pique, A., Poisson, A., Sandulescu, M., Sapunov, I.G., Seghedi, A., Soussi, M., Tchoumatchenko, P.V., Vaslet, D., Vishnevskaya, V., Volozh, Y.A., Voznezenski, A., Walley, C.D., Wong, T.E., Ziegler, M., Barrier, E., Bergerat, F., Bracene, R., Brunet, M.F., Cadet, J.P., Guezou, J.C., Jabaloy, A., Lepvrier, C., Rimmele, G., De, W.P., Baudin, F., Belaid, A., Bonneau, M., Coutelle, A., Fekirine, B., Guillocheau, F., Hantzpergue, M., Julien, M., Kokel, F., Lamarche, J., Mami, L., Mansy, J.L., Mascle, G., Pascal, C., Robin, C., Stephenson, R., Sihamdi, N., Vera, J.A., and VuKs, V.J., 2000, Early Kimmeridgian (146-144 Ma), in Dercourt, J., Gaetani, M., Vrielynck, B., Barrier, E., Biju Duval, B., Brunet, M.F., Cadet, J.P., Crasquin, S., and Sandulescu, M., eds., Peri-Tethys Atlas: Palaeogeographical Maps; Explanatory Notes: Commission for the Geologic Map of the World, Paris, p. $85-97$.
TIEDT, L., 1958, Die Nerineen der österreichischen Gossauschichten: Sitzungsberichte der Österreichischen Akademie der Wissenschaften, MathematischNaturwissenschaftliche Klasse, v. 167, p. 483-517.

VermeIJ, G.J., 1977, The Mesozoic marine revolution: Evidence from snails, predators and grazers: Paleobiology, v. 3, p. 245-258.

VerMEIJ, G.J., 1989, Interoceanic differences in adaptation: Effects of history and productivity: Marine Ecology Progress Series, v. 57, p. 293-305.

Vermej, G.J., 1993, A Natural History of Shells: Princeton University Press, Princeton, New Jersey, 207 p.

Vermeis, G.J., Zipser, E., and Dudley, E.C., 1980, Predation in time and space: Peeling and drilling in terebrid gastropods: Paleobiology, v. 6, p. 352-362.

Voget, K., 1968, Zur Lebensweise des Gastropoden Nerinea: Neues Jahrbuch für Geologie und Paläontologie: Monatshefte, v. 3, p. 181-84.

Wenz, W., 1939, Gastropoda: Pt. 1, Allgemeiner Teil und Prosobranchia, in Schindewolf, O.H., ed., Handbuch der Paläozoologie: vol. 6, Gebrüder Bornträger, Berlin, p. 817-827.

WiecZorek, J., 1975, The taxonomy and life environment of the Upper Jurassic nerineid gastropods from the genus Fibuloptygmatis Pchelintsev (1965): Acta Geologica Polonica, v. 25, p. 153-162.

WieCZoReK, J., 1979, Upper Jurassic nerineacean gastropods from the Holy Cross Mountains (Poland): Acta Palaeontologica Polonica, v. 24, p. 299-350.

WIECZOREK, J., 1992, Biogeography of the Jurassic and the Cretaceous nerineacean gastropods: Abstracts of the 29th International Geological Congress, Kyoto, Japan, p. 106.

Woodring, W.P., 1952, A Nerinea from the southwestern Oriente Province, Cuba: Journal of Paleontology, v. 26, p. 60-63.

Yager, P.L., Nowell, A.R.M., and Jumars, P.A., 1993, Enhanced deposition to pits: A local food source for benthos: Journal of Marine Research, v. 51, p. 209-236. ZiegleR, B., 1964, Boreale Einflüsse im Oberjura Westeuropas: Geologische Rundschau, v. 54 , p. $250-261$

Ziegler, B., ed., 1983, Einführung in die Paläobiologie: Pt. 2, Spezielle Paläontologie, Protisten, Spongien und Coelenteraten, Mollusken: E. Schweizerbart'sche Verlagsbuchhandlung, Stuttgart, 409 p.

ACCEPTED MARCH 23, 2008 